\title{
PENGARUH MODEL PEMBELAJARAN KOOPERATIF TIPE TALKING STICK TERHADAP SIKAP SOSIAL DAN HASIL BELAJAR IPS
}

\author{
Ni Kadek Rosdianti Pertiwi ${ }^{1}$, I Nyoman Murda ${ }^{2}$, Ni Wayan Rati ${ }^{3}$
}

${ }^{123}$ Jurusan Pendidikan Dasar Universitas Pendidikan Ganesha, Singaraja

\begin{abstract}
Abstrak
Permasalahan yang ada dalam penelitian ini yaitu rendahnya sikap sosial siswa dalam proses pembelajaran serta rata-rata hasil belajar IPS siswa kelas IV SD Gugus VIII Kintamani yang mencapai KKM yaitu $46,35 \%$ dan yang belum mencapai KKM yaitu 53,65\%. Rendahnya sikap sosial dan hasil belajar IPS diduga dipengaruhi oleh beberapa faktor, salah satunya yaitu guru kurang menggunakan model pembelajaran yang inovatif. Oleh sebab itu, penelitian ini bertujuan untuk mengetahui pengaruh model pembelajaran kooperatif tipe Talking Stick berbasis lagu daerahterhadap sikap sosial dan hasil belajar IPS. Penelitian ini merupakan penelitian quasi experiment dengan desain nonequivalent post-test only kontrol group. Jumlah populasi dalam penelitian ini adalah 112 orang dan sampel penelitian berjumlah 53 orang yang diambil dengan teknik cluster sampling. Data sikap sosial siswa dikumpulkan menggunakan metode non tes berupa kuesioner dan data hasil belajar IPS dikumpulkan menggunakan tes pilihan ganda. Data dianalisis dengan statistik deskriptif dan Manova. Hasil penelitian menunjukkan bahwa: 1) terdapat perbedaan sikap sosial antara siswa yang mengikuti model pembelajaran kooperatif tipe Talking Stick berbasis lagu daerah dengan siswa yang mengikuti pembelajaran konvensional $\left.\left(F_{\text {hitung }}=99,75>F_{\text {tabel }}=4,00\right) ; 2\right)$ terdapat perbedaan hasil belajar antara siswa yang mengikuti model pembelajaran kooperatif tipe Talking Stick berbasis lagu daerah dengan siswa yang mengikuti pembelajaran konvensional ( $\left.F_{\text {hitung }}=25,32>F_{\text {tabel }}=4,00\right)$ dan 3 ) secara simultan, terdapat perbedaan sikap sosial dan hasil belajar IPS siswa yang mengikuti model pembelajaran kooperatif tipe Talking Stick berbasis lagu daerah dengan siswa yang mengikut pembelajaran konvensional $(F=53,635<0,05)$. Berdasarkan temuan tersebut, dapat disimpulkan bahwa model pembelajaran kooperatif tipe Talking Stick berbasis lagu daerah berpengaruh positif terhadap sikap sosial dan hasil belajar IPS siswa.
\end{abstract}

Keywords: talking stick, lagu daerah, sikap sosial, IPS

\section{Pendahuluan}

Salah satu tujuan pendidikan adalah menyiapkan individu untuk dapat beradaptasi atau menyesuaikan diri untuk memenuhi tuntutan-tuntutan sesuai wilayah tertentu yang senantiasa berubah. Meningkatkan kulitas pendidikan merupakan tanggung jawab semua pihak yang terlibat dalam pendidikan.Salah satu pemegang peran penting dalam meningkatkan kualitas pendidikan adalah guru. Guru adalah salah satu komponen manusiawi dalam proses pembelajaran, yang ikut berperan dalam pembentukan sumber daya manusia yang berkualitas. 
Implementasi Kurikulum 2013 yaitu pembelajaran pada Pendidikan Dasar dan Pendidikan Menengah. Sekolah Dasar (SD) merupakan tempat formal pertama sesorang untuk mendapatkan pengalaman dan pengetahuan mengenai lingkungan sekitarnya serta berinteraksi dengan individu lainnya. Kurikulum 2013, kemampuan kognitif peserta didik diarahkan untuk mengetahui, memahami, menerapkan, menganalisis, dan mengevaluasi ilmu pengetahuan, teknologi, seni dan budaya yang dipelajari dalam konteks sosial-kebangsaan. Pada tingkat usia sekolah dasar tentu membutuhkan suatu pembelajaran yang konkret agar mempermudah peserta didik memahami atau menemukan langsung pengetahuannya yang tentunya didukung oleh pembelajaran yang menarik. Salah satu ciri pembelajaran Kurikulum 2013 adalah pembelajaran tematik integratif yang merupakan pendekatan pembelajaran yang mengintegrasikan berbagai kompetensi dari berbagai mata pelajaran ke dalam sebuah tema. Salah satu muatan materi dalam pembelajaran di SD yaitu muatan materi IPS. "Pendidikan IPS (sosial studies) bukanlah suatu program pendidikan disiplin ilmu, melainkan suatu kajian tentang masalah-masalah sosial" (Lasmawan, 2010:4). Menurut Susanto (2013:5) "Hasil belajar yaitu perubahan-perubahan yang terjadi pada diri siswa, baik yang menyakut aspek kognitif, afektif, dan psikomotor sebagai hasil dari kegiatan belajar".Sedangkan menurut Abdurrahman (dalam Jihad, 2008:14) Hasil belajar adalah kemampuan yang diperoleh anak setelah melalui kegiatan belajar. Belajar itu sendiri merupakan suatu proses dari seseorang yang berusaha untuk memperoleh suatu bentuk perubahan perilaku yang relatif menetap. Kegiatan pembelajaran atau kegiatan intruksional, biasanya guru menetapkan tujuan belajar. Siswa yang berhasil dalam belajar adalah yang berhsil mencapai tujuan-tujuan pembelajaran atau tujuan intuksional. Berdasarkan pendapat tersebut, maka hasil belajar adalah perubahan perilaku yang diperoleh siswa setelah mengikuti proses belajar. Hasil yang diperoleh siswa tersebut berupa perubahan dalam aspek kognitif, afektif, dan psikomotornya.

Hubungan pembelajaran IPS dengan karakteristik siswa usia sekolah dasar yaitu masa kanak-kanak akhir berada dalam tahap oprasi konkreat dalam berpikir yaitu usia 7-12 tahun, anak mulai berpikir logis terhadap objek yang konkreat, rasa egonya berkurang dan mulai bersikap sosial. Cakra (2015) "Sikap sosial adalah kesadaran dari dalam diri individu yang mempengaruhi terhadap lingkungan sosial". Sejalan dengan pengertian sikap yang dijelaskan sebelumnya, maka dapat dipahami bahwa sikap sosial adalah sikap yang ditumbuhkan dan dipelajari sepanjang perkembangan orang yang bersangkutan dalam keterkaitannya dengan obyek tertentu. Sikap sosial merupakan suatu tindakan seseorang untuk hidup dalam masyarakat seperti saling membantu, saling menghormati, saling berinteraksi, dan sebagainya. Sikap sosial sangat dibutuhkan untuk menjalin hubungan dengan orang lain dalam kehidupan sehari-hari serta dapat menciptakan suasana hidup yang damai, rukun, nyaman, dan tentram.

Namun kenyataannya, berdasarkan kegiatan lapangan yang dilakukan melalui wawancara, observasi, dan studi dokumen diperoleh guru masih jarang dalam memanfaatkan media dan model pembelajaran saat proses pembelajaran sehingga pembelajaran menjadi kurang menarik. Selain itu siswa masih memiliki paradigma berpikir bahwa muatan materi IPS adalah pelajaran yang sulit, membosankan, dan hanya sebatas menghafal, siswa kurang berani dalam mengutarakan pendapat, pada proses pembelajaran kurang bervariasi model 
yang guru gunakan. pada saat penyajian hasil diskusi oleh salah satu kelompok, siswa yang lain kurang memperhatikan. Ada yang yang bercanda, dan terkadang mengejek teman yang salah dalam memberikan jawaban atau tidak bisa menjawab pertanyaan yang diberikan oleh guru. Selain itu, kurangnya interaksi siswa dengan lingkungan sehingga sikap sosial siswa masih sangat rendah. Dilihat dari rata-rata nilai hasil belajar IPS siswa kelas IV SD di Gugus VIII Kintamani yang mencapai KKM yaitu $46,35 \%$ dan rata-rata siswa yang belum mencapai KKM yaitu 53,65\%. Melalui hasil pencatatan dokumen tersebut dapat diklasifikasikan bahwa nilai mata pelajaran IPS siswa kelas IV SD Gugus VIII Kintamani masih rendah.

Sehingga untuk mengatasi permasalahan yang ada diperlukan suatu pembelajaran dengan kolaborasi aktif dari interaksi antara guru, siswa, sumber belajar, dan lingkungan belajar. Selain itu, salah satu yang memiliki peran aktif dalam keberhasilan atau pemecahan masalah pembelajaran adalah dengan adanya suatu inovasi baru dalam pembelajaran. Untuk mewujudkan keberhasilan siswa dalam pembelajaran, tentu diperlukan suatu pembelajaran yang berkualitas sehingga mampu memfasilitasi siswa untuk mencapai tujuan pembelajaran. Salah satu cara untuk mewujudkannya yaitu dengan diuji cobakan suatu model pembelajaran yaitu model pembelajaran kooperatif tipe Talking Stick berbasis lagu daerah. "Talking Stick merupakan model pembelajaran kelompok dengan bantuan tongkat" Huda (2014:224). "Model pembelajaran Talking Stick merupakan model pembelajaran yang mengajak siswa belajar sambil bermain sehingga proses pembelajaran menjadi menyenangkan siswa dan materi dapat tersalurkan dengan optimal" (Utami, 2016:3). Adapun keunggulan model Talking Stick adalah melatih siswa memahami materi dengan cepat dan mengajarkan siswa untuk bisa mengeluarkan pendapat sendiri dan mengasah pengetahuan serta pengalaman siswa. Selain itu untuk menumbuhkan motivasi siswa perlu adanya pembelajaran yang menyenangkan. Contohnya pembelajaran yang diimbangi dengan permainan pada saat kegiatan pembelajaran dengan menggunakan teknik permainan dapat menumbuhkan minat siswa untuk belajar. Dalam hal ini permainan yang dilakukan adalah dengan menyanyikan lagu derah yang mereka senangi dalam setiap pembelajaran.

Lagu daerah merupakan kekayaan bangsa, sudah seharusnya dilestarikan dan dikenalkan ke seluruh warga Indonesia. Bukan hanya sekedar mengetahui dan memahami keanekaragaman budaya, tapi yang lebih penting adalah mengkokohkan persatuan dan kesatuan bangsa. Mengenalkan lagu daerah sebaiknya dilakukan sejak dini, misalnya di sekolah dasar dengan mengajak menyanyikan atau memainkan bersamaan alat musik yang sederhana."Lagu daerah memiliki ciri unik dan berbeda dengan masing-masing daerah, gaya bahasa dalam lirik lagunya sesuai dengan susunan bahasa masing-masing daerah" (Trianti, 2017:292).

Penelitian ini memiliki beberapa tujuan antara lain untuk mengetahui dan mendeskripsikan. (1) perbedaan sikap sosial antara siswa yang mengikuti model pembelajaran kooperatif tipe Talking Stick berbasis lagu daerah dan siswa yang megikuti pembelajaran konvensional. (2) perbedaan hasil belajar IPS antara siswa yang mengikuti model pembelajaran kooperatif tipe Talking Stick berbasis lagu daerah dan siswa yang megikuti pembelajaran konvensional. (3) perbedaan secara simultan sikap sosial dan hasil belajar IPS antara siswa yang mengikuti model pembelajaran kooperatif tipe Talking Stick berbasis lagu daerah dan siswa yang megikuti pembelajaran konvensional. 


\section{Metode}

Penelitian ini merupa penelitian eksperimen semu (quasy experiment). Mengingat tidak semua variabel (gejala yang muncul) dan kondisi eksperimen dapat diatur dan dikontrol secara ketat. Desain eksperimen yang digunakan adalah rancangan nonequivalent post-test only kontrol group design. Penelitian ini subjek dari populasi dikelompokkan menjadi dua kelompok yaitu eksperimen dan kontrol. Populasi dalam penelitian ini adalah seluruh siswa kelas IV Sekolah Dasar Gugus VIII Kintamani yang berjumlah 112 orang yang terbagi dalam 5 kelas.

Sebelum dilakukan penentuan sampel penelitian, dilakukan uji kesetaraan pada semua sekolah yang ada di Gugus VIII Kintamani. Data yang digunakan dalam uji kesetaraan adalah nilai ulangan akhir semester (UAS) ganjil mata pelajaran IPS kelas IV Sekolah Dasar. Secara keseluruhan untuk menguji kesetaraan nilai hasil ulangan akhir semester ganjil siswa kelas IV Gusus VIII Kintamani digunakan uji Anava Satu Jalur. Berdasarkan hasil uji kesetaran setiap anggota populasi berhak ikut dalam pengundian penentuan sampel penelitian.

Pengambilan sampel dalam penelitian ini menggunakan teknik cluster sampling. Pengacakan yang dilakukan dalam penelitian ini adalah acak kelas. Berdasarkan pengundian untuk memperoleh kelas eksperimen dan kontrol, diperoleh sampel yaitu siswa kelas IV di SDN Suter sebagai kelompok eksperimen dan siswa kelas IV di SDN Abangsongan sebagai kelompok kontrol. Penelitian ini menggunakan metode nontes untuk mengukur sikap sosial dengan menggunakan instrument kuesioner yang berjumlah 20 pernyataan, dan menggunakan metode tes untuk mengukur hasil belajar IPS dengan instrument pilihan ganda sebanya 30 butir soal.

Teknik analisis data yang digunakan adalah analisis deskriftif dan uji prasyarat analisis. Analisis statistik deskriptif digunakan untuk memberikan gambaran umum mengenai penyebaran data yang diperoleh. Berdasarkan hal tersebut maka dicari mean, median, modus, dan standar deviasi setiap variabel yang diteliti. Sedangkan uji prasyarat analisis dalam penelitian ini terdiri dari uji normalitas sebaran data, uji homogenitas varians, dan uji korelasi antar variabel terikat. Uji prasyarat ini dilakukan sebelum melakukan uji hipotesis. Pengujian hipotesis dalam penelitian ini menggunakan uji Anava Satu Jalur untuk hipotesis satu dan dua, sedangkan untuk hipotesis ke tiga menggunakan uji Manova.

Deskripsi data dikelompokan menjadi 4, yaitu: (1) sikap sosial siswa yang mengikuti model pembelajaran Talking Stick berbasis lagu daerah, (2) hasil belajar IPS siswa yang mengikuti model pembelajaran Talking Stick berbasis lagu daerah,(3) sikap sosial siswa yang mengikuti model pembelajaran konvensional, (4) hasil belajar IPS yang mengikuti model pembelajaran konvensional. Deskripsi data meliputi pengukuran rata-rata hitung, median, modus, standar deviasi, range, nilai minimum, dan nilai maksimum. Berikut adalah penyajian rangkuman statistik deskriptif untuk memudahkan mendiskripsikan masing-masing variable.

4

Pengaruh Model Pembelajaran Kooperatif Tipe Talking Stick Terhadap Sikap Sosial Dan Hasil Belajar Ips 
Tabel 1.

Rangkuman Statistik Deskriptif Variabel Penelitian

\begin{tabular}{lcccc}
\hline & \multicolumn{2}{c}{ Sikap Sosial } & \multicolumn{2}{c}{ Hasil Belajar IPS } \\
\cline { 2 - 5 } Statistik & Eksperimen & Kontrol & Eksperimen & Kontrol \\
\hline $\mathrm{N}$ & 26 & 27 & 26 & 27 \\
Mean & 87,35 & 71 & 81,5 & 73,30 \\
Median & 89,1 & 69,5 & 81,9 & 73,25 \\
Modus & 90,3 & 65,5 & 83 & 72,64 \\
Standar Deviasi & 5,36 & 6,41 & 5,46 & 5,89 \\
Varians & 29,67 & 41,07 & 29,86 & 34,73 \\
Range & 21 & 21 & 24 & 24 \\
Minimum & 78 & 60 & 70 & 60 \\
Maksimum & 98 & 80 & 93 & 83
\end{tabular}

Data tentang sikap sosial siswa pada mata pelajaran IPS yang mengikuti pembelajaran dengan model pembelajaran Model Talking Stick berbasis lagu daerah dengan $n=26$, diperoleh rata-rata sebesar 87,35, median sebesar 89,1 modus sebesar 90,3, nilai maksimum 98, nilai minimum 78, rentangan 21, banyak kelas 6, dan panjang kelas interval 4. Distribusi frekuensi data sikap sosial siswa yang mengikuti model pembelajaran kooperatif tipe Talking Stick berbasis lagu daerah dapat dilihat dalam histogram berikut.

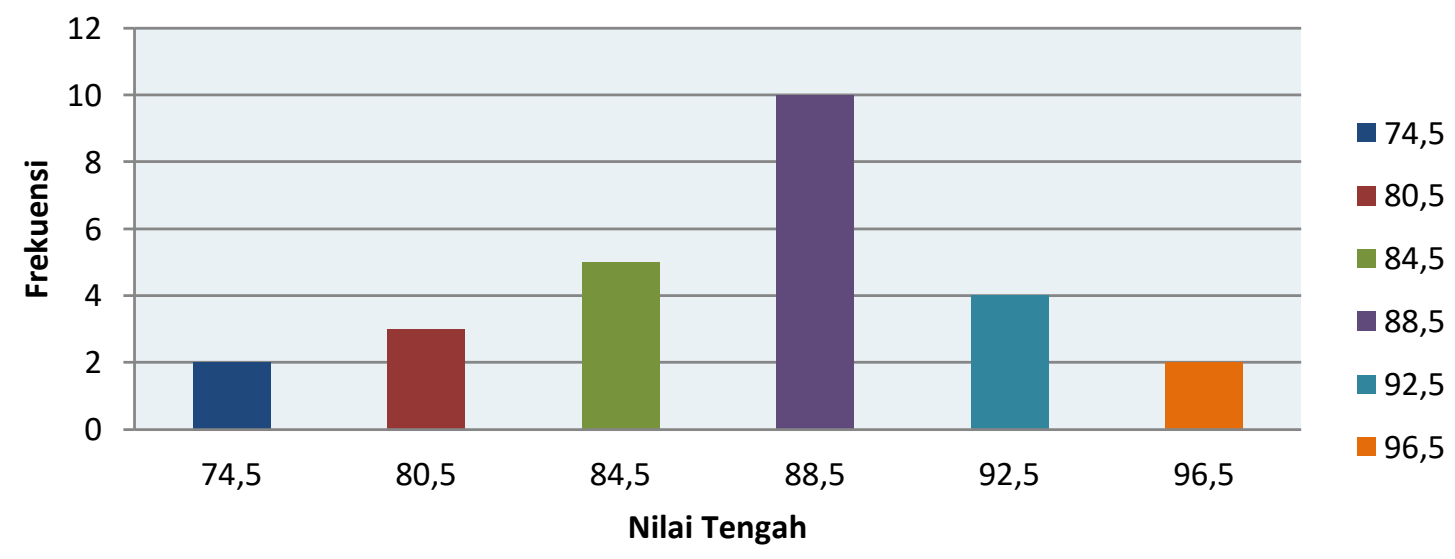


Untuk mengetahui kualitas variabel sikap sosial pada kelas eksperimen, nilai rata-rata sikap sosial siswa dikonversikan ke dalam kategori Klasifikasi Skala Lima Penilaian Acuan Ideal Teoritik. Berdasarkan hasil konvensi, diperoleh bahwa nilai rata-rata sikap sosial siswa kelompok eksperimen, dengan M = 87,35 tergolong kriteria "Sangat Tinggi".

Data tentang hasil belajar siswa pada mata pelajaran IPS yang mengikuti pembelajaran dengan model pembelajaran Model Talking Stick berbasis lagu daerah dengan $\mathrm{n}=26$, diperoleh rata-rata sebesar 81,5, median sebesar 81,9 modus sebesar 83, nilai maksimum 93, nilai minimum 70 , rentangan 24 , banyak kelas 6 , dan panjang kelas interval 4 . Distribusi frekuensi data hasil belajar IPS siswa yang mengikuti model pembelajaran kooperatif tipe Talking Stick berbasis lagu daerah dapat dilihat dalam histogram berikut.

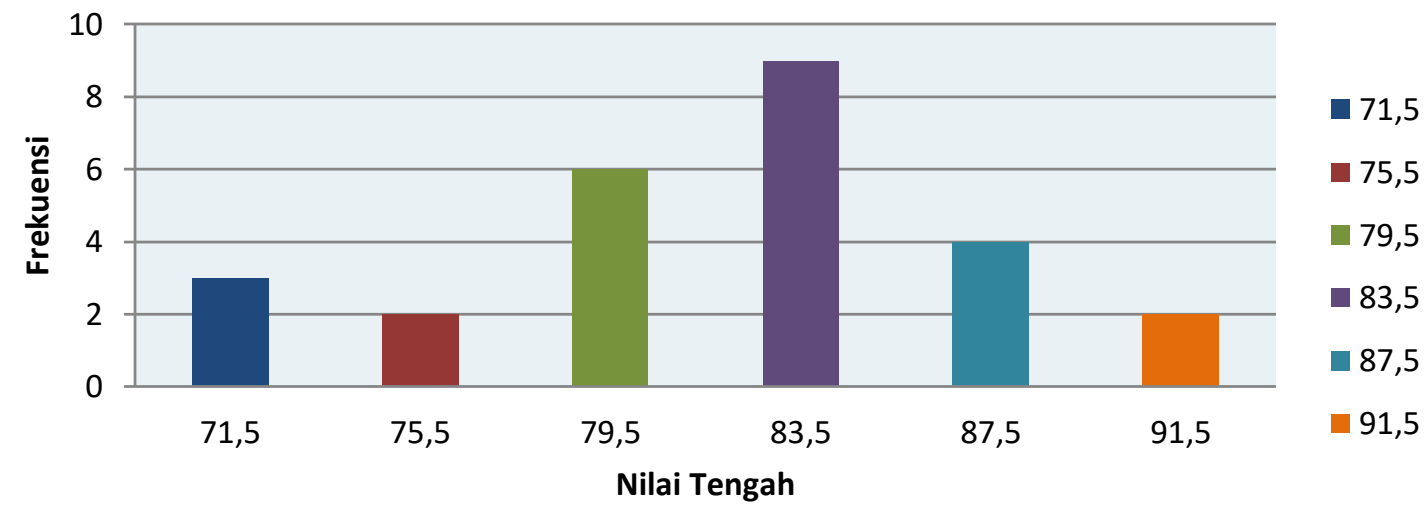

Gambar 2. Histogram Data Hasil Belajar IPS Kelompok Eksperimen

Untuk mengetahui kualitas variabel hasil belajar IPS pada kelas eksperimen, nilai ratarata hasil belajar IPS siswa dikonversikan ke dalam kategori Klasifikasi Skala Lima Penilaian Acuan Ideal Teoritik. Berdasarkan hasil konvensi, diperoleh bahwa nilai rata-rata hasil belajar IPS siswa kelompok eksperimen, dengan M = 81,61 tergolong kriteria "Sangat Tinggi".

Data tentang sikap sosial siswa pada mata pelajaran IPS yang mengikuti pembelajaran dengan pembelajaran konvensional dengan $\mathrm{n}=27$, diperoleh rata-rata sebesar 71 , median sebesar 69,5 modus sebesar 65,5, nilai maksimum 80, nilai minimum 60, rentangan 21 , banyak kelas 6, dan panjang kelas interval 4. Distribusi frekuensi data sikap sosial siswa yang mengikuti pembelajaran konvensional dapat dilihat dalam histogram berikut.

6 


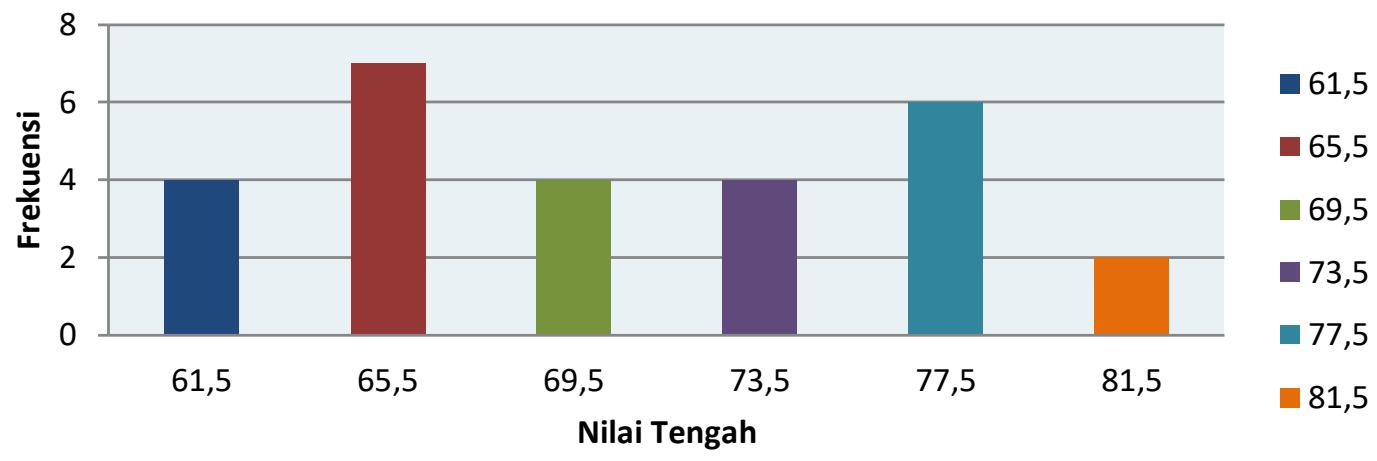

Gambar 3. Histogram Data Sikap Sosial Kelompok Kontrol

Untuk mengetahui kualitas variabel sikap sosial pada kelas kontrol, nilai rata-rata sikap sosial siswa dikonversikan ke dalam kategori Klasifikasi Skala Lima Penilaian Acuan Ideal Teoritik. Berdasarkan hasil konvensi, diperoleh bahwa nilai rata-rata sikap sosial siswa kelompok kotrol, dengan $\mathrm{M}=71$ tergolong kriteria "Tinggi"

Data tentang hasil belajar siswa pada mata pelajaran IPS yang mengikuti pembelajaran dengan Pembelajaran konvensional dengan $n=27$, diperoleh rata-rata sebesar 73,30, median sebesar 73,25 modus sebesar 72,64, nilai maksimum 833, nilai minimum 60, rentangan 24 , banyak kelas 6, dan panjang kelas interval 4. Distribusi frekuensi data hasil belajar IPS siswa yang mengikuti pembelajaran konvensional dapat dilihat dalam histogram berikut.

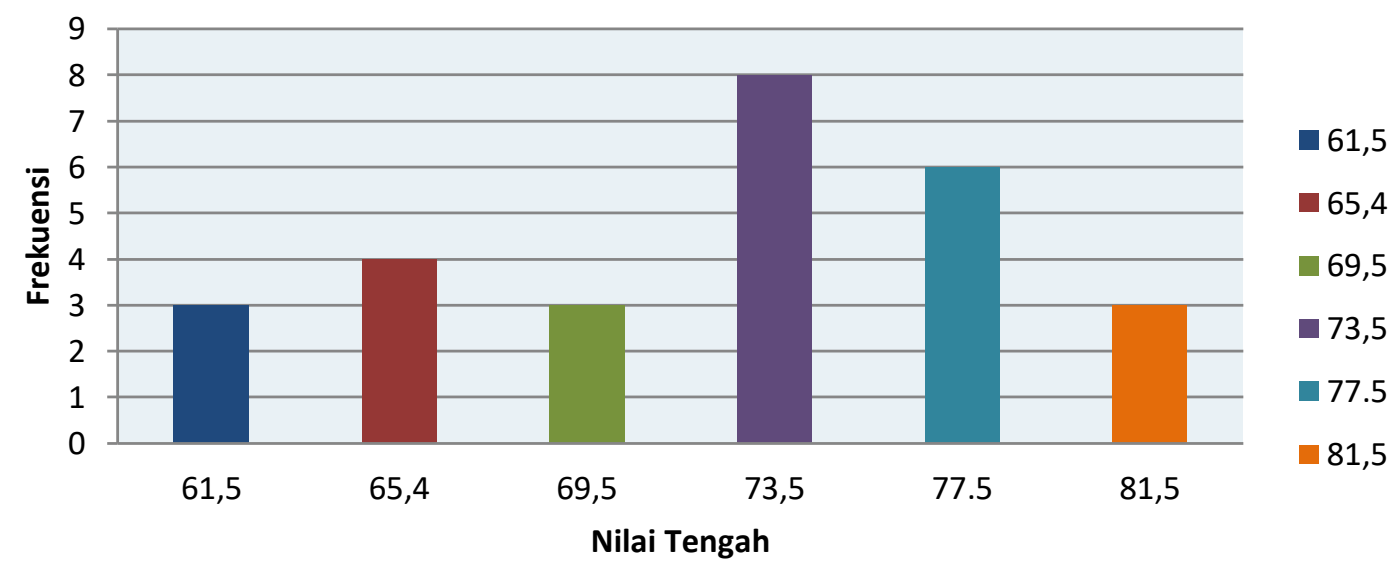

Gambar 2. Histogram Data Hasil Belajar IPS Kelompok Kontrol

Untuk mengetahui kualitas variabel hasil belajar IPS pada kelas kontrol nilai rata-rata hasil belajar IPS siswa dikonversikan ke dalam kategori Klasifikasi Skala Lima Penilaian 
Acuan Ideal Teoritik. Berdasarkan hasil konvensi, diperoleh bahwa nilai rata-rata hasil belajar IPS siswa kelompok eksperimen, dengan M = 73,30 tergolong kriteria "Tinggi".

Sebelum dilakukan uji hipotesis, terlebih dahulu dilakukan uji prasyarat analisis sebagai syarat melakukan uji hipotesis. Uji analisis prasyarat yang dilakukan meliputi: 1) uji normalitas, 2) uji homogenitas, 3) uji korelasi antar variabel.

Uji normalitas dilakukan untuk mengetahui data yang diperoleh berdistribusi normal atau tidak. Uji normalitas data dilakukan dengan menggunakan uji Chi- Kuadrat dengan kriteria pengujian data distribusi normal jika $\chi^{2}$ hitung $<\chi^{2}$ tabel pada taraf signifikansi $5 \%$ dan derajat kebebasan $\mathrm{dk}=$ (jumlah baris -1 ), maka data berdistribusi normal. Berdasarkan hasil analisis diperoleh bahwa: 1) nilai signifikasi data $\chi^{2}$ hitung sikap sosial kelompok kontrol lebih kecil dari $\chi^{2}$ tabel $\left.(7,423<12,592), 2\right)$ nilai signifikasi data $\chi^{2}$ hitung hasil belajar IPS kelompok eksperimen lebih kecil dari $\chi^{2}$ tabel $\left.(9,158<12,592), 3\right)$ nilai signifikasi data $\chi^{2}$ hitung sikap sosial kelompok kontrol lebih kecil dari $\chi^{2}$ tabel $\left.(5,972<12,592), 4\right)$ nilai signifikasi data $\chi^{2}$ hitung hasil belajar IPS kelompok kontrol lebih kecil dari $\chi^{2}$ tabel $(4,722<12,592)$. Sehingga dapatdisimpulkan bahwa keseluruhan data berdistribusi normal.

Uji homogenitas dilakukan terhadap varians pasangan antar kelompok eksperimen dan kontrol.Uji yang digunakan adalah uji-F dengan kriteria data homogen jika $F_{\text {hitung }}<\mathrm{F}_{\text {tabel. }}$ Berdasarkan hasil analisis diperoleh bahwa Fhitung sikap sosial kelompok eksperimen dan kelompok kontrol adalah 1,38, sedangkan $F_{\text {tabel }} 3,99$ menunjukkan $F_{\text {hitung }}(1,38)<F_{\text {tabel }}(3,99)$, dan hasil analisis diperoleh bahwa Fhitung hasil belajar IPS kelompok eksperimen dan

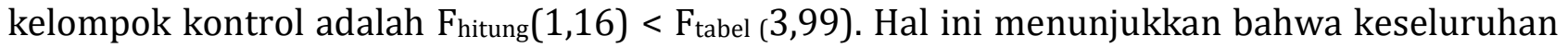
data sikap sosial dan hasil belajar adalah homogen.

Uji korelasi antar variabel terikat dilakukan dengan menggunakan uji product moment dengan kriteria $r_{x y}$ hitung lebih kecil dari $r_{x y}$ table, maka variabel terikat penelitian tidak berkorelasi. Berdasarkan hasil analisis diperoleh korelasi antar variabel terikat pada kelompok eksperimen yaitu sikap sosial dan hasil belajar IPS dengan $\left(r_{x y}\right.$ hitung $=0,11<r_{x y}$ tabel $=0,404$ ), sedangkan pada kelompok kontrol diperoleh nilai $r_{x y}$ hitung lebih kecil dari $r_{x y}$ tabel $\left(r_{x y}\right.$ hitung $=0,36<r_{x y}$ tabel $\left.=0,39\right)$, sehingga dapat disimpulkan bahwa antara variabel sikap sosial dan variabel hasil belajar IPS pada kelompok kontrol tidak berkorelasi.

Berdasarkan hasil uji prasyarat yang meliputi uji normalitas, uji homogenitas varians, dan uji korelasi antar variabel terikat dapat disimpulkan bahwa data yang dipakai dalam penelitian ini dapat diteruskan untuk dipakai dalam pengujian hipotesis.

Setelah melakukan uji prasyarat analisis, maka dilanjutkan dengan uji hipotesis. Hipotesis satu dan dua diuji dengan menggunakan Anava Satu Jalur dengan kriteria pengujiannya jika $F_{\text {hitung }} \geq F_{\text {tabel }}$ pada taraf signifikansi $5 \%$ atau $1 \%$, maka $H_{1}$ diterima dan $H_{0}$ ditolak. Berdasarkan analisis hipotesis satu, diperoleh nilai $\mathrm{F}_{\text {hitung }}$ lebih besar daripada $\mathrm{F}_{\text {tabel }}$ ( $\mathrm{F}_{\text {hitung }}=$ 99,75> $\mathrm{F}_{\text {tabel }}=4,00$ ), sehingga $\mathrm{H}_{0}$ ditolak $\mathrm{H}_{1}$ dan diterima. Jadi, dapat disimpulkan bahwa terdapat perbedaan sikap sosial antara siswa yang mengikuti model pembelajaran Talking Stick berbasis lagu daerah dengan siswa yang mengikuti pembelajaran konvensional pada

8

Pengaruh Model Pembelajaran Kooperatif Tipe Talking Stick Terhadap Sikap Sosial Dan Hasil Belajar Ips 
siswa kelas IV SD Gugus VIII Kintamani Tahun Pelajaran 2018/2019. Berdasarkan analisis hipotesis dua, diperoleh nilai $F_{\text {hitung }}$ lebih besar daripada $F_{\text {tabel }}\left(F_{\text {hitung }}=25,32>F_{\text {tabel }}=4,00\right.$ ) sehingga $\mathrm{H}_{0}$ ditolak $\mathrm{H}_{1}$ dan diterima. Jadi, dapat disimpulkan bahwa terdapat perbedaan Hasil belajar IPS antara siswa yang mengikuti model pembelajaran Talking Stick berbasis lagu daerah dengan siswa yang mengikuti pembelajaran konvensional pada siswa kelas IV SD Gugus VIII Kintamani Tahun Pelajaran 2018/2019.

Pengujian hipotesis tiga menggunakan rumus MANOVA. Kriteria dalam pengujian hipotesis tiga adalah jika harga F untuk analisis Pillais's Trace, Wik Lamda, Hotelling Trance, Roy's Large Root signifikansinya kurang dari 0,05 maka $\mathrm{H}_{0}$ ditolak dan $\mathrm{H}_{1}$ diterima. Berdasarkan hasil analisis, nilai F Pillai's Trace, Wilks' Lambda, Hotelling's Trace, Roy's Largest Root adalah 53,635 seluruhnya memiliki signifikansi 0,000 dan lebih kecil dari 0,05 $(0,000<$ 0,05), sehingga $\mathrm{H}_{0}$ ditolak dan $\mathrm{H}_{1}$ diterima. Berdasarkan hasil analisis uji hipotesis tiga dapat disimpulkan bahwa terdapat perbedaan simultan sikap sosial dan hasil belajar IPS antara siswa yang mengikuti pembelajaran model kooperatif tipe Talking Stick berbasis lagu daerah dan siswa yang mengikuti pembelajaran konvensional pada siswa kelas IV SD gugus VIII Kintamani.

\section{Hasil dan Pembahasan}

Dari proses analisis hipotesis 1 hasil analisis data sikap sosial menunjukkan terdapat perbedaan sikap sosial antara siswa yang mengikuti model pembelajaran Talking Stick berbasis lagu daerah dengan siswa yang mengikuti pembelajaran konvensional. Setelah pemberian kuesioner di akhir pembelajaran, didapatkan hasil rata-rata nilai sikap sosial siswa yang mengikuti model pembelajaran Talking Stick berbasis lagu daerah sebesar 87,35. Sedangkan, siswa yang mengikuti pembelajaran konvensional memperoleh nilai rata-rata 71. Hal ini menunjukkan sikap sosial kelompok siswa yang dibelajarkan dengan model pembelajaran Talking Stick berbasis lagu daerah lebih tinggi dibandingkan dengan kelompok siswa yang mengikuti pembelajaran konvensional.

Perbedaan sikap sosial antara siswa yang mengikuti model pembelajaran Talking Stick berbasis lagu daerah dengan siswa yang mengkuti model pembelajaran konvensional disebabkan oleh diterapkannya model pembelajaran Talking Stick pada kegiatan pembelajaran. Berdasarkan hasil pengamatan dalam proses pembelajaran IPS yang menggunakan model pembelajaran Talking Stick berbasis lagu daerah, ada tahapan siswa belajar dalam kelompok yang heterogen. Melalui kerjasama dalam kelompok siswa dapat saling berinteraksi, bekerjasam dalam menyelesaikan tugas yang dierikan oleh guru, dan saling menghormati dengan siswa lainnya tanpa memandang jenis kelamin maupun agama dari temannya. Penjelasan ini dipertegas oleh pendapat dari Sholihatin \& Raharjo (2011:4) yang menyatakan bahwa pembelajaran kooperatif adalah suatu sikap atau perilaku bersama dalam bekerja atau membantu diantara sesama dalam struktur kerja sama yang teratur dalam kelompok, yang terdiri dari dua orang atau lebih di mana keberhasilan kerja sangat dipengaruhi oleh keterlibatan dari setiap anggota kelompok itu sendiri.

Pada saat tahap memainkan model pembelajaran Talking Stick dikolaborasikan dengan lagu daerah, siswa bernyanyi dengan melemparkan tongkat kepada teman sebelahnya yang membuat suasana pembelajaran menjadi menyenangkan. Sejalan dengan pendapat yang 
dikemukakan oleh Kurniasih \& Berlin (2016) yang menyatakan bahwa "model pembelajaran ini dilakukan dengan bantuan tongkat". Dalam proses pembelajarannya, siswa diajak untuk bernyanyi sambil memegang tongkat secara bergiliran, tongkat tersebut terus berjalan dari satu siswa ke siswa lainnya sampai lagu tersebut selesai dinyanyikan. Siswa yang memegang tongkat terakhir harus siap menjawab pertanyaan yang diberikan guru dan jika tidak bias menjawab pertanyaan dari guru teman sekelompoknya dapat membantu untuk menjawabnya. Berbagai keunggulan yang dimiliki model pembelajaran Talking Stick berbasis lagu daerah sangat membantu dalam mengoptimalkan sikap sosial yang sangat bermanfaat dalam interksi sosialnya sehari-hari serta untuk hidup dalam lingkungan masyarakat. Berdasarkan hasil analisis dan diperkuat oleh penelitian lain yang sesuai dengan penelitian ini, maka dapat disimpulkan bahwa terdapat perbedaan sikap sosial antara siswa yang mengikuti model pembelajaran tipe Talking Stick berbasis lagu daerah dengan siswa yang mengikuti model pembelajaran konvensional pada siswa kelas IV SD Gugus VIII Kintamani Tahun Pelajaran 2018/2019.

Dari proses analisis hipotesis 2 hasil analisis data hasil belajar IPS menunjukkan terdapat perbedaan hasil belajar IPS antara siswa yang mengikuti model pembelajaran Talking Stick berbasis lagu daerah dengan siswa yang mengikuti pembelajaran konvensional. Siswa yang mengikuti model pembelajaran Talking Stick berbasis lagu daerah memperoleh hasil belajar rata-rata yaitu 81,5 lebih tinggi dibandingkan dengan siswa yang mengikuti pembelajaran konvensional yang hanya memperoleh nilai rata-rata 73,30. Hal ini menunjukkan hasil belajar kelompok siswa yang dibelajarkan dengan model pembelajaran Talking Stick berbasis lagu daerah lebih tinggi dibandingkan dengan hasil belajar kelompok siswa yang mengikuti pembelajaran konvensional.

Berdasarkan hasil pengamatan dalam proses pembelajaran IPS yang menggunakan model pembelajaran Talking Stick berbasis lagu daerah suasana pembelajaran menjadi akif dan siswa dilatih untuk berani menyampaikan pendapatnya. Menurut Wijayanti (2017) menyatakan bahwa "model pembelajaran kooperatif tipe talking stick merupakan model pembelajaran yang menuntut siswa untuk aktif berpendapat atau menjawab pertanyaan yang diberikan guru dengan bantuan tongkat." Tongkat dijalankan secara bergilir, siswa yang memegang tongkat wajib menjawab soal yang diberikan oleh guru. Sebelum pelaksanaan Talking Stick siswa harus menyiapkan diri dengan mempelajari materi pokok melalui bimbingan guru. Saat pembelajaran terlihat siswa belajar menjadi lebih aktif dan bersemangat dalam menggali informasi atau materi bersama guru maupun teman kelompoknya. Siswa terlihat sangat aktif berinteraksi dengan guru atau antar teman kelompok untuk bertanya dan saling bertukar informasi mengenai materi yang dipelajari siswa. Dengan bantuan tongkat siswa menjadi lebih berani berbicara untuk mengemukakan pendapanya di dalam kelompok besar. Model ini cocok digunakan pada proses pembelajaran terlihat pada proses pembelajaran yang berlangsung siswa sangat tertarik untuk belajar dan siswa menjadi lebih aktif. Hal ini dikarenakan siswa dilibatkan secara langsung dalam proses pembelajaran sehingga memperoleh pengalaman belajar yang bermakana. Pernyataan tersebut sejalan dengan pendapat dari Kurniasih \& Sani (2016) "model pembelajaran Talking Stick dipakai sebagai tanda seseorang mempunyai hak suara (berbicara) yang diberikan secara bergiliran 
atau bergantian." Berdasarkan penelitian yang telah dilakukan dan diperkuat oleh pendapat di atas, maka model pembelajaran Talking Stick berbasis lagu daerah berpengaruh terhadap hasil beajar IPS siswa.

Dari proses analisis hipotesis 3 hasil analisis data tentang sikap sosial dan hasil belajar IPS menunjukkan, terdapat perbedaan yang simultan antara siswa yang mengikuti model pembelajaran Talking Stick berbasis lagu daerah dengan siswa yang mengikuti pembelajaran konvensional. Siswa yang mengkuti model pembelajaran Talking Stick berbasis lagu daerah memperoleh hasil analisis, nilai F Pillai's Trace, Wilks' Lambda, Hotelling's Trace, Roy's Largest Root adalah 53,635 seluruhnya memiliki signifikansi 0,000 dan lebih kecil dari 0,05 (0,000< 0,05), hal ini menunjukkan terdapat perbedaan secara simultan sikap sosial dan hasil belajar IPS antara siswa yang mengikuti model pembelajaran Talking Stick berbasis lagu daerah dengan siswa yang mengikuti pembelajaran konvensional pada siswa kelas IV SD Gugus VIII Kintamani.

Berdasarkan hasil pengamatan dalam proses pembelajaran IPS yang menggunakan model pembelajaran Talking Stick berbasis lagu daerah, siswa telah menunjukkan interaksi dengan teman kelompoknya, siswa mulai aktif dalam proses pembelajaran, siswa berani mengemukakan pendapatnya, dan siswa lebih senang dalam belajar. Dalam proses pembelajaran, terlibatnya siswa secara langsung melalui kegiatan permainan membuat siswa menjadi lebih tertarik dengan kegiatan pembelajaran. Siswa terlihat lebih brani dalam menyampaikan pendapatnya karena dengan menggunakan model pembelajaran Talking Stick siswa yang memegang tongkat harus menjawab pertanyaan dari guru. Dalam diskusi kelompok siswa bekerjasama dalam menyelesaikan masalah atau tugas yang diberikan guru, setelah siswa selesai berdiskusi siswa menyampaikan hasil diskusinya di depan kelas terlihat siswa yang lain menghargai masukan yang diberikan guru dan teman yang lainnya. Pejelasan tersebut sejalan dengan pendapat Wijayanti (2017) menyatakan bahwa model pembelajaran Talking Stick dapat merangsang siswa aktif dalam proses pembelajaran, melatih siswa berbicara untuk menyampaikan pendapat, mengajarkan siswa untuk berkerjasama dalam suatu kelompok, dan mengembangkan sikap saling menghargai pendapat.

Terlibatnya siswa secara langsung dalam kegiatan pembelajaran juga akan membuat siswa lebih mengingat dan memahami materi yang sudah dipelajari sehingga proses pembelajaran lebih bermakana, dengan demikian maka model pembelajaran kooperatif tipe Talking Stick berpengaruh terhadap hasil belajar. Pernyataan tersebut sejalan dengan pendapat yang dikemukkan oleh Wahyudiantari (2015) juga menyatakan model pembelajaran kooperatif tipe talking stick lebih memicu keaktifn siswa dan menarik siswa dalam proses pembelajaran. Selain itu, pengalaman belajar yang lebih mengaktifkan siswa akan sangat berpengaruh pada kualitas hasil belajar siswa.

Berdasarkan hasil penelitian yang telah dilakukan dan dapat diperkuat dengan pendapat di atas, diketahui bahwa sikap sosial siswa meningkat setelah mengikuti model pembelajaran Talking Stick berbasis lagu daerah, begitu pula dengan hasil belajar IPS siswa meningkat setelah mengikuti model pembelajaran Talking Stick berbasis lagu daerah. Hal ini menunjukkan bahwa terdapat perbedaan secara simultan sikap sosial dan hasil belajar IPS siswa. Semakin tinggi sikap sosial siswa, maka semakin tinggi pula pemahaman hasil belajar 
IPS yang dimiliki siswa. Sebaliknya, semakin rendah sikap sosial siswa, maka semakin rendah pula hasil belajar IPS yang dimiliki siswa. Sehingga dapat dikatakan terdapat perbedaan secara simulan sikap sosial dan hasil belajar IPS siswa.

\section{Simpulan}

Berdasarkan hasil pengujian hipotesis dalam penelitian ini, dan sesuai dengan pembahasan yang telah dilakukan, maka dapat disimpulkan bahwa: 1)Terdapat perbedaan sikap sosial antara siswa yang mengikuti pembelajaran model kooperatif tipe Talking Stick berbasis lagu daerah dan siswa yang mengikuti pembelajaran konvensional pada siswa kelas IV SD gugus VIII Kintamani Tahun Pelajaran 2018/2019. 2)Terdapat perbedaan hasil belajar IPS antara siswa yang mengikuti pembelajaran model kooperatif tipe Talking Stick berbasis lagu daerah dan siswa yang mengikuti pembelajaran konvensional pada siswa kelas IV SD gugus VIII Kintamani Tahun Pelajaran 2018/2019. 3) Terdapat perbedaan simultan sikap sosial dan hasil belajar IPS antara siswa yang mengikuti pembelajaran model kooperatif tipe Talking Stick berbasis lagu daerah dan siswa yang mengikuti pembelajaran konvensional pada siswa kelas IV SD gugus VIII Kintamani Tahun Pelajaran 2018/2019. Jadi, berdasarkan perbedaan yang sudah dijelaskan maka model pembelajaran kooperatif tipe Talking Stick berbasis lagu daerah berpengaruh terhadap sikap sosial dan hasil belajar IPS siswa kelas IV SD Gugus VIII Kintamani Tahun Pelajaran 2018/2019.

Berdasarkan dengan hasil yang diperoleh dalam penelitian in, adapun saran yang dikemukakan adalah 1) Saran terhadap siswa yaitu, siswa-siswa di SD tempat penelitian ataupun siswa di SD lain agar lebih aktif dalam mengikuti pembelajaran, mampu menggali pengetahuan yang dimiliki secara mandiri ataupun berkelompok, guna mengembangkan sikap sosial yang telah dimiliki siswa serta mengembangkan kemampuan pengetahuan IPS siswa itu sendiri. 2) saran terhadap guru yaitu, guru dalam membelajarkan IPS agar lebih inovatif dalam memilih model pembelajaran dan media pembelajaran yang akan diterapkan pada proses pembelajaran. Sehingga pembelajaran lebih efektif dan menarik, tidak monoton, serta dapat meningkatkan sikap sosial dan hasil belajar siswa. 3) Saran kepada kepala sekolah, disarankan agar dapat menciptakan kondisi yang mampu mendorong para guru untuk mencoba menerapkan model pembelajaran Talking Stick Berbasis Lagu Daerah dalam mata pelajaran IPS dan mata pelajaran lain pada umumnya dalam upaya meningkatkan sikap sosial dan hasil belajar. 4) Saran kepada peneliti lain yaitu, peneliti yang berminat untuk mengadakan penelitian lebih lanjut tentang model pembelajaran Talking Stick berbasis lagu daerah dalam bidang ilmu lainnya. Penelitian ini sebagai bahan pertimbangan untuk perbaikan dan penyempurnaan penelitian yang akan dilaksanakan.

oodhyantipertiwi@gmail.com¹ $\underline{\text { inyoman.murda@undiksha.ac.id } 2 \text { niwayan.rati@undiksha.ac.id }{ }^{3}}$

12

Pengaruh Model Pembelajaran Kooperatif Tipe Talking Stick Terhadap Sikap Sosial Dan Hasil Belajar Ips 


\section{Daftar Rujukan}

Cakra, G. 2015. "Pengaruh Penggunaan Metode Pembelajaran Bermain Peran Terhadap Sikap Sosial dan Kemampuan Berbicara Bahasa Indonesia Siswa Kelas VI SD N 29 Dangin Puri Tahun Pelajaran 2014/2016".Jurnal Program Studi Penelitian dan Evaluasi Pendidikan. Singaraja: Undiksha. Volume 5, No 1 Tahun 2015.

Huda, Miftahul. 2014. Model-model Pengajaran dan Pembelajaran. Yogyakarta: Pustaka Pelajar.

Jihad, Asep. 2008. Evaluasi Pembelajaran. Jakarta: Multi Presindo

Kurniasih, Imas \& Berlin Sani. 2016. Ragam Pengembangan Model Pembelajaran untuk MeningkatkanProfesionalitas Guru, Jogjakarta:Kata Pena.

Lasmawan, Wayan. 2010. Menelistik Pendidikan IPS. Singaraja: Mediakom Indonesia Press Bali.

Solihatin \& Raharjo. 2011. Cooperative Learning Analisis Model Pembelajaran IPS. Jakarta: Bumi Aksara

Trianti Lestari. 2017. "Pengaruh Model Pembelajaran Talking Stick Berbantuan Lagu daerah Terhadap Hasil Belajar IPS". Universitas Pendidikan Ganesha. Volume 1 Nomor 4.Tersedia pada http://ejournal.undiksha.ac.id/index.php/JPGSD.(Diakses pada 24 Desember 2018).

Utami Widya. 2016. "Penerapan Model Talking Stick Berbantuan Media Ular Tangga untuk Meningkatkan Motivasi dan Hasil belajar IPA Siswa kelas IV SD Negeri 5 Dauhwaru Keamatan Jembrana Kabupaten Jembrana Tahun Pelajaran 2015/2016". Universitas Pendidikan Ganesha. Volume 4 Nomor 1.Tersedia pada http://ejournal.undiksha.ac.id/index.php/JJPGSD/article/view/7114.(Diakses Tanggal 24 Desember 2018). 
Wahyudiantari, I Gst A A. 2015. "Pengaruh Model Pembelajaran Kooperatif Tipe Talking Stick Berbantuan Multimedia Pembelajaran Interaktif dalam Meningkatkan Hasil belajar IPA siswa kelas VIII di SMP N 7 Singaraja". Singaraja: e-Journal Edutech Undiksha. Volume : 3 Nomor: 1 Tahun: 2015.

Wijayanti, Desi. 2017. "Pengaruh Model Pembelajaran Kooperatif Tipe Talking Stick Berbantuan Media Audio Visual Terhadap Hasil Belajar IPS". Universitas Pendidikan Ganesha. Volume 5 No 2. 
